\title{
Metastatic Pancreatic Neuroendocrine Tumor
}

National Cancer Institute

\section{Source}

National Cancer Institute. Metastatic Pancreatic Neuroendocrine Tumor. NCI Thesaurus.

Code C156488.

A neuroendocrine tumor that arises from the islet cells of the pancreas and has spread to another anatomic site. 